Article

\title{
Four Sustainability Goals in a Swedish Low-Growth/Degrowth Context
}

\author{
Eléonore Fauré ${ }^{1, *}$, Åsa Svenfelt ${ }^{1}$, Göran Finnveden ${ }^{1}$ and Alf Hornborg ${ }^{2}$ \\ 1 Division of Environmental Strategies Research, KTH Royal Institute of Technology, 10044 Stockholm, \\ Sweden; asa.svenfelt@abe.kth.se (Å.S.); goran.finnveden@abe.kth.se (G.F.) \\ 2 The Department of Human Geography and the Human Ecology Division, Faculty of Social Sciences, \\ Lund University, 22100 Lund, Sweden; alf.hornborg@hek.lu.se \\ * Correspondence: eef@kth.se; Tel.: +46-8-790-8664
}

Academic Editor: Vincenzo Torretta

Received: 29 June 2016; Accepted: 18 October 2016; Published: 25 October 2016

\begin{abstract}
Continual environmental degradation and an unfair distribution of environmental burdens and benefits are two great challenges for humanity. Economic growth is often taken for granted when planning for the future. However, it is often argued that maintaining economic growth conflicts with keeping human activities adjusted to ecological boundaries and finite resources, at least for the more-developed countries. With this paper, we present sustainability goals for building and planning in Sweden to be achieved by 2050 in a context of limited or even negative economic growth. These goals should ensure that all groups in society have sufficient resources and a good life within planetary boundaries. We select four goals in a participatory process: two environmental goals related to climate change and land use and two social goals related to welfare and participation. Our results show that achieving the environmental goals will require significant reductions of Sweden's greenhouse gas (GHG) emissions and land use compared to today's levels. Regarding the social goals, these are, in many aspects, reasonably well fulfilled in Sweden today, although disparities remain between groups of citizens. The main challenge, however, is to ensure that these goals are fulfilled even within environmental limits and if economic growth should halt.
\end{abstract}

Keywords: sustainability goals; degrowth; environmental justice

\section{Introduction}

Continued depletion of natural resources, emissions of GHGs and other harmful substances, as well as unsustainable management of ecosystem services threaten to undermine the very basis for human wellbeing [1-3]. Currently the main policy goal in many societies, regardless of current living standards, is directed towards increasing economic growth, even if the discourse has recently evolved towards the notions of sustainable and inclusive growth e.g., UN Sustainable Development Goal (SDG) 8 [4].

There are two main problems with a continued focus on economic growth. Firstly, there is a great deal of uncertainty about future economic growth. Several countries have experienced severe economic decline and long-term estimates show a decline in the global economic growth [5]. Relying on continued economic growth is therefore risky in the sense that possibilities to adapt and be prepared if development should take a different turn than expected are low [6].

Secondly, maintaining economic growth can conflict with keeping human activities adjusted to ecological boundaries and finite resources $[7,8]$ as well as ensuring social justice and human well-being. Environmental burdens and the benefits reaped are unevenly distributed around the globe and between different groups. The exports from less-developed to more-developed countries allow the latter to externalize consumption-based environmental costs, which means that environmental degradation 
in the exporting countries increases as a result of trade [9-11]. When it comes to consumption of environmental goods, i.e., the benefits, the pattern is reversed. The average living standards in Europe and North America using current technologies cannot be universalized for the current seven billion people on the planet because they are founded on an overconsumption of natural resources [12].

Despite the negative impacts related to increased production and consumption, the focus continues to be placed on economic growth rather than asking how the economy could be used as a tool to achieve sustainability goals. We propose instead to start out from what should be achieved i.e., define social and environmental goals and ask what future societies might be like if they were fulfilled. Economic growth is thus not seen as a prerequisite. This issue, to explore sustainable societies that stay within planetary boundaries and ensure that all groups in society have sufficient resources and a good life, is a main research question in the project Beyond GDP Growth-Scenarios for Sustainable Building and Planning. In the project, we will develop normative, backcasting scenarios [13,14]. A first step is then to define the goals that the scenarios should fulfil. One starting point could be the UN 17 Sustainable Development Goals and associated targets that governments have agreed on [4]. This list of goals and targets is comprehensive but difficult to use in practical work on national levels unless they are operationalised. It is also challenging in research contexts e.g., for the use in backcasting scenarios where a more limited number of goals is necessary in order to be manageable. One of the UN SDGs, goal 8, is also specifically about sustainable economic growth and employment. However, in our project and this specific paper, we question this focus on continued economic growth.

The aim of this paper is to select, operationalise and discuss a set of sustainability goals for a Swedish context. We do this by addressing the following two questions:

- Which social and ecological goals are most relevant to explore in the Swedish context, and why?

- How could the selected goals be operationalised into a Swedish context?

Although the goals are for Sweden, the aim is to set them in a global context acknowledging the need for defining a just and safe operating space [15], thereby encompassing both an inter- and an intragenerational perspective. The novel aspect of this paper is to select and operationalise both social and environmental goals of high relevance for Swedish society in 2050. The chosen sustainability goals will eventually be used as a basis for the construction of normative backcasting scenarios in which these specific sustainability goals are fulfilled in different ways. The process for choosing and defining these goals is described below but early versions of the backcasting scenarios themselves are shown elsewhere [16].

As the goals are long-term and are subject to great uncertainty, they are formulated in such a manner as to allow them to be achieved in different ways in different possible futures, depending on potential future policy contexts or prevailing norms. This is done in order to avoid lock-ins.

\section{Background}

There are many definitions and interpretations of sustainability and sustainable development. The most well-known is probably the Brundtland definition, stating that it is a "development that meets the needs of the present without compromising the ability of future generations to meet their own needs" [17]. Recently, a modified version of this definition has been suggested by Griggs et al., emphasizing the environmental pressure put by human activity on the same Earth system that human livelihoods depend upon. This definition states a "Development that meets the needs of the present whilst safeguarding Earth's life-support system upon which the welfare of current and future generations depends" [18] (p. 306).

However, the term sustainable development has been criticised and is even seen as a paradox since it assumes that development is an inherent part of sustainability, and development, it is argued, is what has dominated the planet for the last two centuries and has caused present social and environmental problems (for example Serge Latouche, cited in [19]). 
An alternative way to understand the meaning of sustainability, and that we will be using in this paper, is through looking at the different suggestions of what is to be achieved, i.e., sustainability goals rather than how it is defined [20,21].

One contribution to the formulation of such goals is the planetary boundaries framework [3,22]. From a mainly environmental perspective, the framework suggests nine goals, or outer boundaries, that should not be overstepped and defines a safe operating space for humanity. The boundaries include, for example, climate change, biosphere integrity and land-use change [3]. Another set of goals are the millennium development goals (MDGs), which are eight goals mainly framed with a social perspective and agreed upon by the UN, to be achieved by 2015 [23]. These are, on the other hand, mainly framed with a social perspective for less-developed countries. The goals include issues such as extreme poverty and hunger eradication, gender equality promotion and women empowerment, as well as child mortality reduction.

The UN sustainable development goals (SDGs) have now been developed as part of the post-2015 Development Agenda [4], combining environmental, social and economic aspects. In comparison to aspects included in the MDGs, they have a broader spectrum that also includes goals related to prosperity, justice and environment and they will be applicable for all countries. Kanie et al. [24] argued that SDGs should integrate human and planetary wellbeing and Griggs et al. [25] have proposed such integrated goals.

As a framework for sustainable development, Raworth [15] integrated social and ecological aspects through defining 'A safe and just space for humanity'. Raworth also presented a doughnut-shaped space between an environmental ceiling represented by the nine planetary boundaries identified by Rockström et al. [22] and a social foundation comprising eleven parameters based on governments' priorities for Rio+20. This doughnut called attention to the fact that the planetary boundaries cannot be seen isolated from social rights and needs. In theory, it might be possible to keep the global society within the planetary boundaries, but with great injustices to large parts of the population. Hence, in order to avoid such injustices and human deprivation, the aspects of the social foundation need to be considered simultaneously as the environmental ceiling. Raworth's influential model, the doughnut of social and planetary boundaries, is an important point of departure for this paper.

The aspects of the doughnut are quite general and adjusted to a global level but attempts have been made to downscale both the doughnut and the planetary boundaries to national levels. In a report for Oxfam UK, Sayers explored how the doughnut could be made relevant to the Scottish context [26]. Cole et al. [27] used South Africa as a test case for the doughnut and as an input to policy-makers on a national level.

Sweden has a set of 16 Swedish National Environmental Quality Objectives ranging from climate change to biodiversity and thriving wetlands [28-30]. In addition, "the generational goal" is overarching and states that the goal is to "hand over to the next generation a society in which the major environmental problems in Sweden have been solved, without increasing environmental and health problems outside Sweden's borders" [28]. Nykvist et al. [31] compared the planetary boundaries with the national environmental objectives and discussed how the planetary boundaries could be adapted to a Swedish context and reflect the international dimension of the national environmental goals.

As discussed above, sustainability includes many interacting aspects and it is therefore necessary to take into account several perspectives and to define several goals. There may be conflicts between competing perspectives and stakes and any policy option can result in winners and losers [32]. It is therefore important to explore if different options seem preferable merely because some perspectives are lacking [32]. Transferred to a sustainability goal setting, this means that if more perspectives and goals are added to policy analysis and policy-making, conflicting goals and measures can be made explicit and ultimately acted upon. In this paper, we address this issue by selecting several goals, not only focusing on one, although we acknowledge that the scope is still limited. 


\section{Method and Process}

\subsection{Empirical Basis}

The method consisted of a literature review, workshops and semi-structured interviews.

The purpose of the literature review was to identify policy goals and alternative suggestions for goals for each aspect of the doughnut in order to create a basis for operationalising the aspects into goals in a Swedish context. The literature review comprised policy documents at the Swedish, European and international level, scientific literature, scenario projects and reports from non-governmental organizations. For each doughnut aspect, the current official goals were first analysed in order to highlight the advantages and drawbacks of each. Out of this analysis more far-reaching goals were formulated.

In order to obtain feedback on the selection of and suggestions for goals, two groups of stakeholders were involved: the project research group and the project partner group with representatives from outside academia. The research group consists of 15 researchers from various disciplines and with different levels of experience from a total of three Swedish universities and two research institutes in Sweden. Five members are men and ten are women. The disciplines include Anthropology, Economics, Environmental Strategic Research, Human Ecology, Planning and Decision Analysis, Political Science, Sociology and Urban and Regional Planning. The competencies include life cycle assessment, both with a focus on the built environment and in general, futures studies, resource metabolism and critical analysis of socio-spatial power relations on a global scale, environmental policy and planning, policy and planning for sustainable land use and transport, green, sustainable and inclusive economy, sustainable mobility, sociocultural perspectives on sustainable development, environmental justice, utopian thought and social movements, and the impact of time-use and perception of time on the environment and the organization of work.

The project partner group consisted of representatives from 11 actors in different sectors in society, including four Swedish municipalities, one Swedish county council, two Swedish governmental agencies, one Swedish ministry, one member-owned bank and two sustainability networks/NGOs. All were selected for their demonstrated interest in participating in the project and in the issues discussed.

Meetings and workshops were organized with participants from the two groups. Usually the issues were discussed in small groups to get the participants' individual feedback and priorities. The selection criteria for the goals were discussed with the research group and the selection and formulation of goals were discussed in both groups.

To complement workshops and obtain more focused input, semi-structured interviews [33] were conducted with six researchers in the project group. Two of them had specific competence in the topics of work and one of them also had knowledge about nitrogen and phosphorus cycle issues. Two researchers had expertise in the built environment and what could be regarded as "a good built environment", which is a Swedish Environmental goal. Finally two researchers were interviewed about gender equity. To gather information on areas where our research group lacked the necessary expertise, we also interviewed four external experts: two researchers in the field of land use, one researcher in the field of crime and crime prevention for the topic of personal security and finally an expert from the Public Health Agency of Sweden. The aim of these interviews was to discuss potential indicators for the corresponding doughnut areas, e.g., how to define good health. The interviews were not transcribed and analysed but merely used to inform the process.

\subsection{Selection Criteria and Selection of Goals}

For practical reasons, we had to limit ourselves to a manageable number of goals. This selection process, carried out with the help of both researchers and a partner group, was therefore crucial to choosing the most pressing sustainability issues in the Swedish context, considering that we could not encompass all issues. 
In order to have a basis for the selection of goals, certain criteria for choosing were developed. In a brainstorming process, the authors formulated 23 potential criteria and the research group was asked to choose the five most important. Four criteria received more than two votes (Table 1) and guided the selection of goals. It should be noted that the selection of criteria are context-dependent and chosen for this project by the project research and partner groups. In other contexts, other criteria and goals may be more important.

Table 1. Criteria for goal selection.

\begin{tabular}{cc}
\hline The Goals Should Be & Verification \\
\hline Easy to operationalise & $\begin{array}{c}\text { Previous operationalisations } \\
\text { Discussion with the project group }\end{array}$ \\
\hline Relevant to planning and policy in Sweden & $\begin{array}{c}\text { Review of existing goals } \\
\text { Discussion with societal partners }\end{array}$ \\
\hline Central to sustainability & Goals in research and in Swedish policies \\
\hline $\begin{array}{c}\text { Everyone in the project should stand behind } \\
\text { the goals as representing sustainability }\end{array}$ & $\begin{array}{c}\text { Project meetings } \\
\text { Workshops with the research group }\end{array}$ \\
\hline
\end{tabular}

In the next step, a preliminary goal was formulated for each doughnut area. Based on the criteria and prioritizations by the partner group and research group members, four of those preliminary goals were chosen. These comprise two ecologically oriented goals relating to climate change and land use change respectively. The other two goals are socially oriented and relate to welfare or resource security (based on Raworth's criteria 'jobs' and 'income' and 'social equity') and fair distribution of power, participation, and influence (approximating Raworth's 'voice,' 'social equity,' and 'gender equality').

Table 2 summarizes how the chosen goals fulfil the selection criteria and is followed by a further description of the goals. Since these four goals are chosen based on the criteria above, they are particularly relevant for Sweden and the project context. However, the chosen goals may also be relevant and useful for the operationalisation of sustainability goals in other contexts.

Table 2. Evaluation of how the chosen goals fulfil the selection criteria and how this is verified.

\begin{tabular}{|c|c|c|c|c|}
\hline The Goals Should Be & Climate & Land-Use & Participation & Welfare/Resources \\
\hline Easy to operationalise & $\begin{array}{l}\text { Possible to quantify } \\
\text { through IPCC's Fifth } \\
\text { Assessment Report } \\
\text { (2013) and Swedish } \\
\text { policy goals. } \\
\text { Discussion with the } \\
\text { project group. }\end{array}$ & $\begin{array}{l}\text { Possible to quantify } \\
\text { through the Global } \\
\text { Footprint Network } \\
2015 \text { (Global } \\
\text { Availability and } \\
\text { Swedish use } \\
\text { per capita). } \\
\text { Discussion with the } \\
\text { project group. }\end{array}$ & $\begin{array}{l}\text { Difficult to quantify } \\
\text { but possible to } \\
\text { operationalise } \\
\text { qualitatively through } \\
\text { Swedish policy goals. } \\
\text { Discussion with the } \\
\text { project group. }\end{array}$ & $\begin{array}{l}\text { Difficult to quantify } \\
\text { but possible to } \\
\text { operationalise } \\
\text { qualitatively through } \\
\text { Swedish policy goals. } \\
\text { Discussion with the } \\
\text { project group. }\end{array}$ \\
\hline $\begin{array}{l}\text { Relevant to planning } \\
\text { and policy in Sweden }\end{array}$ & & $\begin{array}{r}\text { Partner } \\
\text { on Swedish Environ }\end{array}$ & $\begin{array}{l}\text { volved } \\
\text { ntal and other policy g }\end{array}$ & als \\
\hline Central to sustainability & Planetary boundary & Planetary boundary & $\begin{array}{c}\text { Doughnut area } \\
\text { (e.g., voice) }\end{array}$ & $\begin{array}{c}\text { Doughnut area } \\
\text { (e.g., social equity) }\end{array}$ \\
\hline $\begin{array}{l}\text { The project should } \\
\text { stand behind } \\
\text { the goals as indicators of } \\
\text { sustainable development }\end{array}$ & \multicolumn{4}{|c|}{ Project group involved in selection and formulation } \\
\hline
\end{tabular}




\section{Results: Operationalization and Analysis of Selected Goals}

\subsection{Climate Change}

Within the planetary boundaries framework, the proposed boundary for climate change is 350 ppm (350-450 ppm range) atmospheric carbon dioxide concentration [3,22], which corresponds to about $450 \mathrm{ppm} \mathrm{CO}_{2}$ eq when all Kyoto GHG are considered [31]. Knowledge of how the climate system reacts is incomplete, for instance regarding the relation between the level of GHG emissions and a specific temperature rise, due to uncertainties in the carbon cycle and the climate response [34].

Two different maximum temperature increases above the pre-industrial level are recurrent in climate discussions: 1.5 and $2{ }^{\circ} \mathrm{C}$ [35] (p. 114). The temperature of $1.5^{\circ} \mathrm{C}$ has been advocated by the countries that are most affected by the impacts of climate change and that have less local capacity to cope with the same impacts, mainly the Alliance of Small Island States (AOSIS) and the Least Developed Countries (LCDs) [36]. Some organisations have also been suggesting this maximum temperature rise or even a lower one $[37,38]$, arguing that a level of $2{ }^{\circ} \mathrm{C}$ would pose too high a risk of ecosystem damage.

The temperature of $2{ }^{\circ} \mathrm{C}$ has otherwise been the yardstick adopted by the countries represented within the United Nations Framework Convention on Climate Change [35,39] after the 2010 Cancun Agreements. It is also the maximum temperature rise, together with a $400 \mathrm{ppm} \mathrm{CO}_{2}$ eq concentration, that has been specified in the current Swedish national goal "Reduced Climate Impact" [40]. Nykvist et al. [31] base their proposed national boundary on figures from the United Nations Development Programme (UNDP) (2007), i.e., a maximum temperature rise of $2{ }^{\circ} \mathrm{C}$ and the derived 2 ton $\mathrm{CO}_{2}$ per year multiplied by the current Swedish population. It is specified, though, that depending on the projected population figures the boundary may have to be revised downwards [31].

However, since the Paris agreement (United Nations Framework Convention on Climate Change [41], the $1.5{ }^{\circ} \mathrm{C}$ limit has been put forward in a more concerted manner. The aim of the agreement is now to "hold the increase in the global average temperature to well below $2{ }^{\circ} \mathrm{C}$ above pre-industrial levels and to pursue efforts to limit the temperature increase to $1.5^{\circ} \mathrm{C}$ above pre-industrial levels, recognising that this would significantly reduce the risks and impacts of climate change" [41].

Rogelj et al. [36] have studied the implications of aiming at less than $1.5^{\circ} \mathrm{C}$ by assessing $1.5^{\circ} \mathrm{C}$ consistent scenarios (more than $50 \%$ likelihood of remaining below $1.5^{\circ} \mathrm{C}$ and more than $66 \%$ of staying under $2{ }^{\circ} \mathrm{C}$ ) against likely $2{ }^{\circ} \mathrm{C}$ scenarios (more than $66 \%$ likelihood of staying under $2{ }^{\circ} \mathrm{C}$ but less than $50 \%$ likelihood of staying under $1.5^{\circ} \mathrm{C}$ ). Consistent scenarios of $1.5^{\circ} \mathrm{C}$ are characterized by lower concentrations ranging from 420 to $440 \mathrm{ppm} \mathrm{CO} \mathrm{CO}_{2} \mathrm{eq}$ in 2100, compared to $450-480 \mathrm{ppm} \mathrm{CO} \mathrm{CO}_{2} \mathrm{eq}$ for the studied likely $2{ }^{\circ} \mathrm{C}$ scenarios [36]. Net global carbon emissions, for instance, would need to be zero by the period 2045-2060, i.e., one or two decades earlier than in the likely $2{ }^{\circ} \mathrm{C}$ scenarios and both types of scenarios assume negative net global emissions in the second half of the century, e.g., with Bio-energy with carbon capture and storage (BECCS) [36]. According to the United Nations Environment Programme (UNEP) [42], the issue of whether a large-scale deployment of technologies to achieve negative emissions is feasible is however highly debatable.

When considering all GHG covered by the Kyoto Protocol, emissions would need to be net zero by the period 2060-2080, i.e., about two decades earlier than for $2{ }^{\circ} \mathrm{C}$ consistent pathways [42] (p. 8).

Common to all $1.5^{\circ} \mathrm{C}$ consistent scenarios is the fact that emission reductions will need to be greater at an earlier stage (2020 and 2030) than in likely $2{ }^{\circ} \mathrm{C}$ scenarios [42] (ibid.). In the models presented by Rogelj et al. [36], energy-related $\mathrm{CO}_{2}$ emissions reductions are between $2 \%$ and $2.8 \%$ per year during the period $2010-2050$ compared to $1.2 \%$ to $1.8 \%$ per year for $2{ }^{\circ} \mathrm{C}$ likely scenarios.

In Sweden, parliament adopted a long-term vision "An emissions-neutral country by 2050 " [28,40] in 2008 which states that there should be no net emissions of greenhouse gases (in $\mathrm{CO}_{2}$ eq) by 2050 . This means that negative emissions can compensate for GHG emissions. It is expected that Carbon Capture and Storage (CCS) will be used [40]. The use of nuclear power is not ruled out [40]. 
The Swedish vision nonetheless only covers emissions within Sweden's territory, i.e., from the production and consumption that occur in the country. Emissions abroad induced by Swedish consumption are not included. Several studies, however, have underlined the fact that the effects of national emissions reduction can be cancelled out by an increase in consumptive emissions in Sweden $[43,44]$. While Swedish territorial emissions have decreased by 30 per cent over the past 20 years, emissions abroad as a result of Swedish consumption have increased by 50 per cent during the same period. From 2010 to 2013, however, total emissions from Swedish consumption (both abroad and in Sweden) have decreased by about 8 per cent [45]. It is however difficult at this stage to predict whether this recent trend will continue.

Choosing a consumption goal, a maximum amount of $\mathrm{CO}_{2}$ equivalents per capita related to Swedish consumption, could account for Sweden's impact outside its borders, consistent with Sweden's Generational Goal [28]. This approach includes both emissions abroad in the whole supply chain caused by Swedish consumption and emissions from international transport but not emissions from the production of goods in Sweden exported to other countries.

To set a quantitative goal, we chose $1.5^{\circ} \mathrm{C}$ as a maximum temperature increase as $2{ }^{\circ} \mathrm{C}$ may imply severe environmental impacts. We therefore here use $1.5^{\circ} \mathrm{C}$ consistent scenarios and the associated suggested levels of emissions per year required to stay under that level by the end of the century. There are fewer scenarios consistent with a $1.5^{\circ} \mathrm{C}$ compared to $2{ }^{\circ} \mathrm{C}$ maximum increase [42]. Even though the likelihood of staying under 1.5 is only between $50 \%$ and $66 \%$, these scenarios are the most stringent to be found in the literature [36]. These pathways assume limited action by 2020, i.e., that only the Cancun pledges will be implemented and then a least cost mitigation, i.e., that emissions reductions start in 2020 and "are optimally distributed over time" [42]. The most recent estimate for global emissions amounted to $52.7 \mathrm{Gt} \mathrm{CO}_{2}$ eq/year in 2014 (range: 47.9-57.5) [42] (p. 3). According to pathways for limiting warming to below $1.5^{\circ} \mathrm{C}$ by 2100, GHG emissions (carbon dioxide, methane, nitrous oxide as well as fluorinated greenhouse gases) will remain slightly above today's level until 2020, $56 \mathrm{Gt} \mathrm{CO}_{2} \mathrm{eq} /$ year (median) and then decline quite steeply to $39 \mathrm{Gt} \mathrm{CO}_{2} \mathrm{eq} /$ year in 2030 and $8 \mathrm{Gt} \mathrm{CO}_{2}$ eq/year in 2050 [42] (p. 8). Emissions will be negative in 2100 ( $-5 \mathrm{Gt} \mathrm{CO}_{2}$ eq/year). If we assume a global population of 9.7 billion people in 2050 (medium variant) [46], the maximum amount of GHG emissions per capita per year would need to decrease to about 0.82 tons $\mathrm{CO}_{2}$ equivalents per capita. If higher or lower global population increases are assumed in our future research, this per capita level will have to be adjusted.

However, having a goal for GHG emissions from Swedish consumption might only lead to a situation where Swedish industries with a large export share could continue to use fossil fuels.

The goal of a fossil-free Sweden by 2050 is therefore to reduce the territorial $\mathrm{CO}_{2}$ emissions and avoid such a situation. This would mean that Swedish production is fossil-free and would allow a limited consumption of goods from other countries that are not.

For climate, we have selected two goals: one aiming at reducing the territorial greenhouse gas emissions and the other one targeting Sweden's consumptive emissions.

Selected Goals

- Sweden is to be fossil-free by 2050, i.e., no fossil fuels are used as fuels or in industrial processes.

- A maximum of 0.82 tons $\mathrm{CO}_{2}$ equivalents (GHG) consumptive emissions per capita per year in Sweden.

By combining a territorial and a consumption-based goal, there could be room for higher per capita emissions from other countries from which Sweden imports goods and Sweden could set a precedent by taking on some historical responsibility through complete adoption of renewable energy.

These goals are set for Sweden, regardless of what other countries do, as we are here discussing how Sweden may be sustainable by 2050 even if no global agreement on mitigation goals is reached. However, the goal for consumptive emissions could be adopted globally as the maximum level of GHGs emissions in order to keep warming under $1.5^{\circ} \mathrm{C}$ is divided equally among the world 
population. Depending on what other countries choose to do, and how much goods Sweden will import, the challenge for Sweden will vary.

In 2012, the emissions from Swedish consumption amounted to 11 tons $\mathrm{CO}_{2}$ eq per capita [45]. Sweden's inhabitants would therefore need to reduce the emissions from consumption by 92 per cent in order to reach the 0.82 tons $\mathrm{CO}_{2}$ eq goal. In 2014, 53 per cent of the energy used in Sweden came from renewable energy sources [47].

\subsection{Land Use}

Population growth and higher levels of consumption have induced increased land use and land-cover changes [48]. Along with the need for fossil-free energy and more food for a growing population, the competition for land and ultimately land scarcity may increase. The planetary boundaries framework includes land use change and the new revised boundary for land use is that the area of forested land should be at least $75 \%$ of the original forest cover [3]. The control variable was changed from the original boundary, amount of cropland [22], because forest is considered to play a stronger role in land surface-climate coupling [3].

Nykvist et al. [31] have attempted to downscale the previous cropland planetary boundary to the Swedish context. They discuss some opportunities but also argue that one key limitation is that the boundary only concerns transformation to cropland although environmental consequences are also associated with other kinds of land-use change (e.g., to built areas, intensively managed forests and pastures).

Sweden has several environmental quality objectives related to specific types of land: Thriving Wetlands, Sustainable Forests, A Varied Agricultural Landscape, A Magnificent Mountain Landscape, A Rich Diversity of Plant and Animal Life, and A Good Built Environment [49]. The goals state that functions, assets and values (natural and cultural) of these different types of land must be protected and preserved for the future. Specific goals are defined for protection and preservation of high nature value forestland and wetlands [49], but there are, at present, no national goals for how much land should be used for different purposes.

Furthermore, products and raw materials are increasingly being traded around the world, which means that land used for consumption is much less related to the local context where consumption takes place. Hence, other options for setting land-use goals need to be explored. One approach would be to calculate ecological footprints [50]. These illustrate a theoretical land area that is required for resource consumption and waste assimilation, especially $\mathrm{CO}_{2}$ sequestration. However, since $\mathrm{CO}_{2}$-emissions are already included in the previous goal, related to climate change, a goal based on ecological footprints seems less relevant. Instead, a goal related to actual land use could be useful.

A land-use goal with a consumption perspective, i.e., land use allocated to and seen through the perspective of the consumption by a country's inhabitant, no matter where the goods are produced [51] could help explore options for land availability, use and distribution. Lenzen and Murray [52] suggest accounts for actual areas of land used for agriculture and forestry that can distinguish land use for imports, domestic production and exports. Similarly, Tukker et al. [53] have calculated land footprints for final consumption. Sandström et al. [54] have calculated the land use embodied in imports and the land embodied in exports to get a "Net displacement" measure of embodied land-use demands related to food in Finland. Their results show that net displacement is increasing and was about 223,000 ha land in 2007.

A goal based on actual land footprints can add a justice perspective to land use as it also incorporates the land use abroad for Swedish consumption and does not allow Sweden more land per capita than other countries simply because it is sparsely populated.

\section{Selected Goal}

- The per capita land area used for final consumption does not exceed the global biocapacity. 
At present, this goal is far from being reached. Global biocapacity is a measure of the amount of biologically productive land and sea area that is available to provide ecosystem services that humanity consumes [55]. In addition to actual land use, the global biocapacity measure also includes land for carbon sequestration. It is measured in global hectares (gha), which is a measurement of the world average bioproductive area (ignoring regional differences in productivity for the benefit of comparison) [55]. If only actual land (cropland, grazing land, forest land and built-up land) and fishing grounds are included, Swedish consumption used 3.5 global hectares per capita in 2011, based on a population of 9.5 million [56]. In order to remain within the earth's biocapacity, which equals 1.7 global hectares per capita based on a world population of 6.998 billion people, Swedish residents should reduce land use for consumption by approximately $50 \%$. In order to maintain this level, and considering population growth (assuming UN medium projection of 9.7 billion people in 2050 [46]), the per capita land use footprint for actual land should be 1.24 global hectares per capita in the world by 2050. This goal cannot only be used for Swedish residents but also on a global level as the available biocapacity is divided equally among the world population.

\subsection{Distribution of Power, Influence and Participation in Society}

Two aspects in Raworth's doughnut [15] deal with distribution of power, influence and participation in society, namely gender equality and voice. Raworth [15] does not suggest any specific goals but discusses, in an illustrative assessment, how far below the social foundation humanity is, at present, for both domains on a global scale. Raworth [15] uses two indicators to illustrate that the gender equality aspect is not met: the representation gap between men and women in national parliaments and the employment gap between men and women in salaried work. Voice is exemplified by the indicator "Population living in countries perceived (in surveys) not to permit political participation or freedom of expression".

Although these indicators are highly relevant on a global scale, the situation in Sweden is somewhat different. The representation of women at different levels of the political arena is high, compared to other countries, for instance in the Swedish Parliament (43.6\%), even if it has decreased slightly at the last two elections, after reaching a peak at the 2006 election [57]. The employment rate in 2013 was $77 \%$ for women and $82 \%$ for men [58]. However, gender distribution is very uneven if we look at specific sectors [58]. Looking at listed companies, women only occupied $5 \%$ of the positions as chairpersons of boards and 6\% of those as CEOs in 2013 [58]. How well these indicators are met therefore depends on which sphere is being considered, whether it be politics, state-owned companies or private companies.

Sweden has adopted an overall objective "to ensure that women and men have the same power to shape society and their own lives" [59]. Four sub-goals are identified: equal distribution of power and influence, economic equality between the sexes, equal distribution of unpaid care and household work, and an end to men's violence against women.

The issue of participation in society is also part of the Swedish National Health goal, whose aim is "to create societal prerequisites for good health on equal terms for the entire population" [60]. For this goal, 11 health determinants are identified and the first one is about participation and influence in society, formulated as follows: "The right to participation and influence in a democratic society applies regardless of gender, gender expression, ethnicity or religion, disability, sexual orientation or age" [61]. Further, it is also emphasized that "particular attention shall be given to strengthening the capacity and opportunity for social and cultural empowerment of economically and socially vulnerable persons and to children's, adolescents' and the elderly's opportunities to influence and participate in society" [61].

In the suggested goal we combine these two areas of gender equality and anti-discrimination in general. Freedom of opinion is included in this goal, as we assumed it is implied in participation in society and allows us to keep the total number of goals more manageable. 
Nussbaum [62] has listed ten central capabilities, i.e., real opportunities based on personal and social circumstances. One is about control over one's environment. Nussbaum distinguishes between two areas: the political and the material. Here, we adapt the former but widen its scope by including other decision contexts that can influence people's life, such as decisions made in the working environment.

Selected Goal

- All residents in Sweden, regardless of, for example, gender, gender expression, sexual orientation, ethnicity and religious affiliation, age, disability, class and income level, should be entitled to participate in and influence political choices and decision-making that affect their lives.

Measuring the achievement of this goal is not easy, although some indicators can be used to assess equality between groups. Achieving equality between groups (e.g., between men and women), however, does not mean that equality between individuals is automatically achieved at the same time, i.e., differences between individuals within the same category may remain the same, depending, for example, on their level of education. For example, as has already been mentioned, women in the private sector usually have less power and influence than men whereas in state-owned or partly state-owned companies, women are better represented than in listed companies [63]. Furthermore, looking only at such numerical indicators may be misleading; another interesting indicator might perhaps be to look at the level of activity and acceptance in parliament. The number of propositions put forward by women could also be of relevance, as well as the proportion of those propositions that is later adopted. Also, when it comes to other aspects, such as differences in participation between foreign-born and native-born citizens in society, the indicators show that there are differences between different groups. At the 2010 general election, the voter turnout was 87 per cent among native-born and only 73 per cent among the foreign-born [64]. Besides, foreign-born people do not get elected to parliament, county councils and municipal positions to the same extent as native-born people [64]. These indicators suggest that, at present, this goal is achieved in some aspects or some areas but not necessarily in all relevant forums.

\subsection{Welfare/Resource Security}

In Raworth's social foundation [15] "jobs", "income", "health" and "social equity" are four domains. What must be achieved regarding jobs and income, however, is not elaborated on further. In an overview of how far below the social foundation humanity is at present, "jobs" are discussed as "labour force not employed in decent work" [15] (p. 10). When it comes to income, Raworth mentions the proportion of the population living below $\$ 1.25$ per day when discussing deprivation beneath the social foundation. The same indicator is formulated as a goal in the Sustainable Development Goal for eradicating poverty, stating that by 2030 no-one should live on less than that [4]. The indicator "Population estimated to be without regular access to essential medicines" used by Raworth [15] illustrates health. Social equity is exemplified by the percentage of the "population living on less than the median income in countries with a Gini coefficient exceeding 0.35" [15].

Income is a traditional measure of poverty, but according to, for example, Maxwell [65], it is inadequate as a description of the same. Instead, the United Nations Human Development Report [66] (p. 14) states that poverty can mean more than a lack of resources; it can also mean a lack of opportunities and chances to lead a healthy and creative life, a decent living standard, freedom, self-esteem and respect from others. The Sustainable Development goals set out to ensure that by 2030 all men and women have equal rights to economic resources and also to basic services, ownership and control over land and other forms of property, inheritance, natural resources, appropriate new technology and financial services, including microfinance [4].

Other authors have suggested indicators for operationalising aspects of the social foundation in the doughnut. For the South African case, Cole et al. [27] use a broad unemployment rate as an indicator of jobs. It includes both the number of people who are unemployed and the people who 
are not working due to illness or disability. Cole et al. [27] also suggest adding the indicator "the employment gap in waged work" to reflect gender equality if data become available. The indicator chosen to illustrate income is income deprivation and is an upper-bound poverty line, below which more than half of the South African population lives [27]. For the Scottish doughnut, Sayers uses relative poverty to illustrate income, which is defined by the indicator "Households below $60 \%$ average income-after housing costs" [26]. For work, the percentage of "people lacking satisfying work" is used as an indicator and adds a quality dimension to the purely quantitative aspect of unemployment figures by including issues such as influence and representation, among other aspects [26].

Existing Swedish goals or goal-related formulations relating to jobs, welfare and income security are, for example, the Instrument of Government (SFS No 1974:152) [67], the second article of which declares that "The personal, economic and cultural welfare of the individual shall be fundamental aims of public activity. In particular, the public institutions shall secure the right to employment, housing and education, and shall promote social care and social security, as well as favourable conditions for good health". Since the Instrument of Government is one of Sweden's constitutional laws, it can be assumed that there is a strong consensus around this formulation.

Employment and income or economic resources are framed as important in the approaches above. However, for goals to be relevant even if transformative change occurs in society, they should stipulate what to achieve (the end) and not how it should be achieved (the means). No-one knows what will happen in the future, so if the goals take into account uncertainty and a broad range of options, they can encompass more radical solutions and future innovation. For example, according to some authors paid work can reduce freedom and creativity when it is merely a necessity in order to secure one's needs $[68,69]$.

Furthermore, in order to have favourable conditions for good health it is important to have enough resources and services. Fairness in the distribution of resources is also important however. According to the Swedish Public Health Agency [70], there is a correlation between good public health and a society characterized by economic and social security, equality and justice.

In light of the above, our suggested goal does not stipulate that jobs, income or financial resources are needed to secure housing, education, social care and social security, and good health. The goal should allow for alternative solutions, such as, for example, trading goods for services directly on a local market, or having a lot of spare time in order to take care of the elderly in the family. However, a discussion on how such activities could be divided between men and women is necessary, as women have typically been responsible for the care of the elderly or children in the past. The goal is divided into two parts in accordance with Ringenson [71]: one related to the level of resources and services and one related to the distribution. The latter should be considered "fair". This term does not, however, have any universal interpretation but needs to be discussed and agreed upon depending on the political context in which it is to be used.

For welfare/resource security, we formulate the two following goals

- Residents in Sweden should have sufficient access to resources and services that can create opportunities for housing, education, social care and social security, as well as favourable conditions for good health.

- The distribution of the same resources and services should be made according to some fairness principle.

The fairness principle referred to above may differ in different contexts, for example due to type of governance and interpretations of what is fair. At present, the first goal above can, to a large extent, be reached for Sweden as a country, although there may be disparities between different groups in society. Most residents in Sweden have access to proper housing, but there are homeless people, 34,000 in 2011 (approximately $0.4 \%$ of the population in that year) [72]. This figure does not include migrants who are only in Sweden temporarily. Regarding education, primary and secondary school education in Sweden is free of charge and should, according to the Swedish Education Act (2010:800) [73], guarantee a similar 
education, independent of gender, geographical location or socio-economic background. However, the National Agency for Education stated in a recent report that opportunities can still vary greatly depending on the student's family background and that this has been aggravated by the free school choice [74].

There are also differences in health between different socio-economic groups [75]. Socially vulnerable groups have poorer health and use healthcare services to a greater extent [75]. Hence, although the goal is close to being reached, this is not so for all Swedish residents. As there are uncertainties about the future development of, for example, the labour market, the financing of welfare, or whether radical transformations will occur in society, future challenges might enhance the risk that this goal will not be met. The goal is therefore important to take into account when exploring alternative future scenarios.

\section{Discussion}

In our deliberations over the many sustainability criteria listed by Rockström et al. [22] and Raworth [15], we soon found ourselves immersed in tricky but important discussions about the merits and disadvantages of dividing sustainability issues into approximately twenty distinct parameters. Lists of different sustainability criteria may give the impression that the different problems are compartmentalized and disconnected from each other. However, this is a simplification that hides the real complexity and the interactions between social and ecological systems. For example, the Millennium Ecosystem Assessment [76] has laid out some of the fundamental linkages between ecosystem services and human well-being. Also, in an environmental justice perspective, the distribution of both ecosystem resources and pollution levels are vital issues of both power and survival [77]. Although undoubtedly useful in contexts such as law, policy, engineering, and some varieties of research, separating sustainability issues into a set of distinct parameters inevitably produces a fragmented perspective on the human predicament in the Anthropocene. However, in order to operationalise goals for future scenarios in Sweden, we had to opt for such a separation. We selected goals to explore in the context of building and planning where the primary purpose is to fulfil sustainability goals, and economic growth is not seen as a prerequisite to fulfil them. Four goals were deemed sufficiently challenging, as it will imply cross-sectorial and interdisciplinary methods and approaches to analyse strategies for fulfilling the goals. Furthermore, these goals will eventually be used in backcasting, which normally only works with one goal at a time. Our aim here is to include both environmental and social goals and increase the number of goals in order to explore whether having several goals could help identify potential goal conflicts at an earlier stage. Therefore, on the one hand, our scope can be said to be narrow, as we only deal with four separate goals, but on the other hand the scope can also be said to be wide, as we propose goals that can form a basis for simultaneously addressing fulfilment of several goals, rather than one, in sustainable building and planning.

It is, however, important that the potential interactions between the goals, goal synergies or conflicts between these four goals and also with other sustainability goals are analysed in order to highlight the necessary trade-offs. This will be the next stage of the project.

Having specific enough goals while avoiding lock-ins and allowing for a variety of future measures and options was also challenging. Other attempts that have been made to adapt the doughnut framework nationally include Sayers [26] and Cole [27], who analyse the situation today for Scotland and South Africa respectively and what should be done to solve social or environmental issues. They do not, however, question and redefine existing areas or concepts (the idea of work, for instance and the separation of work time and leisure time). Looking ahead, future society might look different and the norms prevailing today may not apply any longer.

We therefore had to formulate goals so that they could allow for different interpretations that can allow for radically transformed societies. The goal "Welfare/resource security", for example, was an important area to explore in our degrowth/low growth context, as many proponents of economic growth argue that growth is needed to create full employment and to pull people out of poverty $[78,79]$. 
Others, such as Victor [7], claim that growth has failed to deliver on these aspects, illustrating that this is a contested topic. We thus do not use the prevailing goals for full employment or reducing unemployment but instead consider what is to be achieved (the opportunities rather than the resources themselves). This goal could be achieved by reducing unemployment but it may also be reached by redefining the concept of work.

Our goals are either per capita or refer to residents in Sweden. Our point of departure was that the persons benefitting from resources and power and participation should be the same as those upon whom restrictions in terms of GHG emissions and land use are put. We then opted for the term "residents in Sweden" to include people with a Swedish residence permit. However, it could be argued that, for instance, the total GHG emissions per year should not be divided between countries based only on population as some countries have emitted or are emitting more than others [80] and historic emissions should play a role in distribution of future emissions. Another justice dimension is the fact that a per capita goal in a country is an average of the emissions per person per year in that specific country. It does not take into account how this may differ depending, for example, on gender [81] or income $[82,83]$.

Our aim was to set national goals in a global context and take into account aspects of inter- and intragenerational perspectives as specified in the Swedish generational goal [28]. Both environmental goals therefore include a consumption perspective to account for the impact of Swedish consumption abroad. They are set for Sweden but could be used globally as they are derived from global goals divided among the global population into per capita levels. The welfare/resources goals, even if they are part of the Rio +20 priorities, are here formulated as Swedish goals. However, these goals could also be used in other contexts or nations.

A challenge for all goals will be to go one step further when our scenarios are developed and study what these goals may mean for different Swedish regions. According to Dearing et al. [84], "natural resource management takes place predominantly at regional scales as part of national and regional development planning." Land management, for example, may therefore need to be explored at a regional or local scale.

When selecting and formulating the goals, we were guided by the criterion that the goals should be relevant to policy and planning and that everyone in the project should stand behind them as representing sustainable development. There is therefore a balance to achieve in setting goals between how realistic and ambitious these should be. Baard [85] suggests setting "cautious utopian" goals as a way to manage long time-frames and epistemic uncertainty. "Cautiously utopian goals are believed, but not certain, to be achievable and to remain desirable, but are open to future adjustments due to changing desires and/or factual circumstances" [85].

We have seen that each of these four goals is challenging compared to the situation today. The task is even more challenging as we are considering them simultaneously and the interactions between the goals need to be made visible. For instance, one prerequisite for the scenarios consistent with $1.5^{\circ} \mathrm{C}$ is both the rapid adoption of BECCS technology but also the reliance on carbon sinks from land-use, e.g., through afforestation in order to achieve net negative emissions during the second half of the century. This could have implications for land use.

There are many uncertainties when it comes to the climate goal. First, knowledge of how the climate system reacts is incomplete, as mentioned earlier. Besides, world population development is also uncertain. According to the UN [46], the world's population may amount to 9.7 billion inhabitants (medium variant) but could vary between 10.8 billion (high variant) (UN, 2015) and 8.7 billion (low variant), which will have consequences when setting a per capita goal.

A point of discussion raised during the process of selecting and formulating goals is that the goals visualized by Raworth as a 'social foundation', i.e., as minimum requirements for social prosperity, may, in themselves, if universalized, put too great demands on the planet and thus transgress the 'environmental ceiling'. The general consensus, in Europe and North America, about what a minimum of social prosperity entails has been shaped by two centuries of economic growth. The question, 
in other words, is if there really is a doughnut-shaped space between the foundation and the ceiling on a global scale, a challenge Raworth only touches upon in her discussion paper. We will not develop it further here but note that this is an issue that needs further attention.

\section{Conclusions}

We have selected and formulated, in a multi-disciplinary group and with the contribution of societal partners, four goals for backcasting scenarios in a context of degrowth and urban planning in Sweden. The implications of these goals will be further studied in the development of the scenarios. For the environmental goals, global ecological boundaries and the impact of Swedish consumption were considered. Social goals were formulated to allow for different normative frameworks and distributive considerations at a national level were included. The two environmental goals imply large reductions in GHG emissions and land use for consumption in Sweden. These goals are also set at a national level but further details might be needed in order to also study the implications at a regional or local level. The goal related to GHG emissions is similar to goals in previous backcasting studies related to, for example, transportation or urban development but are developed further here, acknowledging both a consumption perspective and a stricter maximum temperature rise. The land-use goal is, however, new and may turn out to be demanding.

Regarding the social goals, these are, in many aspects, reasonably well fulfilled in Sweden today although many challenges remain in order to ensure similar opportunities for all Swedish residents. The main challenge, however, is to ensure that these goals are fulfilled even within environmental limits and even if the economy stagnates or economic growth is negative.

Here, we have defined only four goals and we realize that many other trade-offs may be needed when considering, for instance, the remaining Swedish Environmental Objectives or other social aspects. We grant that it would be valuable to also operationalise other aspects of the doughnut into goals. This will however not be done as part of this research project. Instead, other environmental and social aspects will be addressed through sustainability assessments. For example, conflicts or synergies with other goals may be examined later on in the project. However, even four goals pose a challenge to backcasting as a method has to be developed to consider all four goals simultaneously.

These four goals are highly relevant to the degrowth context but can also be useful to look at in other contexts and for the use of other multi-target backcasting projects. The exercise of downscaling global goals to a national level is also a challenge. We suggest that the goals developed here may also be relevant for other countries with a similar economic profile, although further contextualization may then be necessary.

Formulating goals such as the ones described in this paper can be a step towards planning and policy that aims to achieve and follow-up important societal goals rather than focusing on economic growth. Implementing such goals in policy and practice would require adequate indicators to measure and follow up goal fulfilment. This is an area that needs further development. The implementation of the SDGs will include the development of indicators for follow-up, which means that better indicators and data on a global level will become available. To base policy on sustainability targets that do not assume continued economic growth would require a letting go of economic growth and income as values that should be strived for and instead shift focus to the qualities that society wishes to achieve.

Acknowledgments: Financial support from Formas is gratefully acknowledged. Many thanks to all members of the project and partner groups of the Beyond GDP Growth Project for their valuable contributions. Valuable comments on a draft were received by Sven-Ove Hansson and Ulrika Gunnarsson-Östling, KTH.

Author Contributions: The content of the paper relies on a collective effort between the four authors. Eléonore Fauré and Åsa Svenfelt wrote most of the paper. Eléonore Fauré wrote specifically parts of the background, the method, the analysis of the goals for climate and participation in society and the conclusions, and contributed to the analysis of the goals for land use and resource security and welfare as well as to the discussion. Assa Svenfelt wrote specifically the introduction, most of the background, the analysis of the goals for land use and resource security and welfare and contributed to the analysis of the goals for climate and participation in society as well as to the discussion. Alf Hornborg and Göran Finnveden are co-authors. Alf Hornborg contributed to the 
introduction and discussion and provided feedback on the method and the paper. Göran Finnveden contributed to the discussion and provided feedback on the method and the paper.

Conflicts of Interest: The authors declare no conflict of interest.

\section{References}

1. McMichael, A.; Scholes, R.; Hefny, M. Linking ecosystem services and human well-being. Ecosyst. Hum. Well-Being 2005, 5, 43-60.

2. Hansen, J.; Kharecha, P.; Sato, M.; Masson-Delmotte, V.; Ackerman, F.; Beerling, D.J.; Hearty, P.J.; Hoegh-Guldberg, O.; Hsu, S.L.; Parmesan, C.; et al. Assessing "dangerous climate change": Required reduction of carbon emissions to protect young people, future generations and nature. PLoS ONE 2013, 8, e81648. [CrossRef] [PubMed]

3. Steffen, W.; Richardson, K.; Rockström, J.; Cornell, S.; Fetzer, I.; Bennett, E.; Biggs, R.; Carpenter, S.; De Vries, W.; De Wit, C.A.; et al. Planetary boundaries: Guiding human development on a changing planet. Science 2015, 348. [CrossRef] [PubMed]

4. UN General Assembly. Transforming Our World: The 2030 Agenda for Sustainable Development; A/RES/70/1. 2015. Available online: http://www.refworld.org/docid/57b6e3e44.html (accessed on 21 October 2016).

5. Gordon, R.J. Is U.S. Economic Growth over? Faltering Innovation Confronts the Sid Headwinds; CEPR Policy Insight No 63. Available online: http:/ / cepr.org/sites/default/files/policy_insights/PolicyInsight63.pdf (accessed on 21 October 2016).

6. Svenfelt, Å.; Engström, R.; Höjer, M. Use of explorative scenarios in environmental policy-making-Evaluation of policy instruments for management of land, water and the built environment. Futures 2010, 42, 1166-1175. [CrossRef]

7. Victor, P. Managing Without Growth Slower by Design, Not Disaster; Edward Edgar Publishing: Cheltenham, UK, 2008.

8. Jackson, T. Prosperity Without Growth: Economics for a Finite Planet; Earthscan: London, UK, 2009.

9. Jorgenson, A.K.; Clark, B. Ecologically Unequal Exchange in Comparative Perspective: A Brief Introduction. Int. J. Comp. Sociol. 2009, 50, 211-214. [CrossRef]

10. Jorgenson, A.K.; Clark, B. Societies consuming nature: A panel study of the ecological footprints of nations, 1960-2003. Soc. Sci. Res. 2011, 40, 226-244. [CrossRef]

11. Hornborg, A. Commentary: Towards an ecological theory of unequal exchange: Articulating world system theory and ecological economics. Ecol. Econ. 1998, 25, 127-136. [CrossRef]

12. World Wide Fund for Nature (WWF). Sammanfattning av Världsnaturfonden WWFs Living Planet Report 2014 (In English: Planet Report 2014 Swedish Summary); Världsnaturfonden WWF: Gland, Switzerland, 2014.

13. Robinson, J.B. Energy backcasting A proposed method of policy analysis. Energy Policy 1982, 10, 337-344. [CrossRef]

14. Dreborg, K.H. Essence of backcasting. Futures 1996, 28, 813-828. [CrossRef]

15. Raworth, K. A Safe and Just Space for Humanity: Can we live within the Doughnut? Oxfam Policy Pract. 2012, 8, 1-26.

16. Svenfelt, Å.; Alfredsson, E.; Aretun, Å.; Bradley, K.; Fauré, E.; Fuehrer, P.; Gunnarsson-Östling, U.; Hagbert, P.; Isaksson, K.; Malmaéus, M.; et al. Bortom BNP-Tillväxt Testversion av Scenarier för Hållbart Samhällsbyggande Bortom BNP-Tillväxt; KTH Royal Institute of Technology: Stockholm, Swedish, 2015.

17. United Nations World Commission on Environment and Development. Our Common Future; Oxford University Press: Oxford, UK, 1987.

18. Griggs, D.; Stafford-Smith, M.; Gaffney, O.; Rockström, J.; Ohman, M.C.; Shyamsundar, P.; Steffen, W.; Glaser, G.; Kanie, N.; Noble, I. Sustainable development goals for people and planet. Nature 2013, 495, 305-307. [CrossRef] [PubMed]

19. Kallis, G.; D'Alisa, G.; Demaria, F. Introduction: Degrowth. In Degrowth: A Vocabulary for a New Era; D'Alisa, G., Demaria, F., Kallis, G., Eds.; Routledge: London, UK, 2015; pp. 1-17.

20. Kates, R.W.; Parris, T.M.; Leiserowitz, A.A. What Is Sustainable Development? Goals, Indicators, Values, and Practice. Environ. Sci. Policy 2005, 47, 8-21. 
21. Robinson, J. Squaring the circle? Some thoughts on the idea of sustainable development. Ecol. Econ. 2004, 48, 369-384. [CrossRef]

22. Rockström, J.; Steffen, W.; Noone, K.; Persson, Å.; Chapin, F.S.; Lambin, E.; Lenton, T.M.; Scheffer, M.; Folke, C.; Schellnhuber, H.J.; et al. Planetary boundaries: Exploring the safe operating space for humanity. Ecol. Soc. 2009, 14, 32. [CrossRef]

23. United Nations (UN) General Assembly. United Nations Millennium Declaration, Resolution Adopted by the General Assembly. Available online: http://www.refworld.org/docid/3b00f4ea3.html (accessed on 21 October 2016).

24. Kanie, N.; Zondervan, R.; Stevens, C. (Eds.) Ideas on Governance 'of' and 'for' Sustainable Development Goals. Available online: https://i.unu.edu/media/ias.unu.edu-en/news/3295/post2015-conference-report. pdf (accessed on 21 October 2016).

25. Griggs, D.; Smith, M.S.; Rockstrom, J.; Ohman, M.C.; Gaffney, O.; Glaser, G.; Kanie, N.; Noble, I.; Steffen, W.; Shyamsundar, P. An integrated framework for sustainable development goals. Ecol. Soc. 2014. [CrossRef]

26. Sayers, M.; Trebeck, K.; Stuart, F. The Scottish Doughnut: A Safe and Just Operating Space for Scotland; Oxfam GB: Oxford, UK, 2014.

27. Cole, M.J.; Bailey, R.M.; New, M.G. Tracking sustainable development with a national barometer for South Africa using a downscaled "safe and just space" framework. Proc. Natl. Acad. Sci. USA 2014, 111, E4399-E4408. [CrossRef] [PubMed]

28. Government Bill. Svenska Miljömål-Miljöpolitik för ett Hållbart Sverige [Swedish Environmental Objectives-Environmental Policy for a Sustainable Sweden]; The Government Offices: Stockholm, Sweden, 1997.

29. Government Bill. The Swedish Environmental Objectives-Interim Targets and Action Strategies; The Government Offices: Stockholm, Sweden, 2000.

30. Government Bill. Svenska Miljömål—ett Gemensamt Uppdrag [Swedish Environmental Objectives-A Joint Mission]; The Government Offices: Stockholm, Sweden, 2004.

31. Nykvist, B.; Persson, Å.; Moberg, F.; Persson, L.; Cornell, S.; Rockström, J. National Environmental Performance on Planetary Boundaries; Swedish Environmental Protection Agency: Stockholm, Sweden, 2013.

32. Munda, G. A conflict analysis approach for illuminating distributional issues in sustainability policy. Eur. J. Oper. Res. 2009, 194, 307-322. [CrossRef]

33. Kvale, S. Den Kvalitativa Forskningsintervjun; Studentlitteratur: Lund, Sweden, 1997.

34. Meinshausen, M.; Meinshausen, N.; Hare, W.; Raper, S.C.B.; Frieler, K.; Knutti, R.; Frame, D.J.; Allen, M.R. Greenhouse-gas emission targets for limiting global warming to 2 degrees C. Nature 2009, 458, 1158-1162. [CrossRef] [PubMed]

35. IPCC (Intergovernmental Panel on Climate Change). Climate Change 2014: Synthesis Report. Contribution of Working Groups I, II and III to the Fifth Assessment Report of the Intergovernmental Panel on Climate Change; IPCC: Geneva, Switzerland, 2014.

36. Rogelj, J.; Luderer, G.; Pietzcker, R.C.; Kriegler, E.; Schaeffer, M.; Krey, V.; Riahi, K. Energy system transformations for limiting end-of-century warming to below $1.5^{\circ} \mathrm{C}$. Nat. Clim. Chang. 2015, 5, 519-527. [CrossRef]

37. Swedish Society for Nature Conservation. Climate Policy; Swedish Society for Nature Conservation: Stockholm, Sweden, 2011.

38. Teske, S.; Muth, J.; Sawyer, S.; Pregger, T.; Simon, S.; Naegler, T.; O'Sullivan, M.; Schmid, S.; Pagenkopf, J.; Frieske, B.; et al. Energy [R]evolution-A Sustainable World Energy Outlook; GWEC: Amsterdam, The Netherlands, 2012.

39. United Nations Framework Convention on Climate Change. Cancun Agreement; United Nations Framework Convention on Climate Change: Bonn, Germany, 2010.

40. The Government Offices. Swedish Government en Sammanhållen Klimat-Och Energipolitik_Klimat [A Sustainable Energy and Climate Policy_Climate]; The Government Offices: Stockholm, Sweden, 2009.

41. United Nations Framework Convention on Climate Change (UNFCCC). Adoption of the Paris Agreement; United Nations Framework Convention on Climate Change: Bonn, Germany, 2015; p. 32.

42. United Nations Environment Programme (UNEP). The Emissions Gap Report 2015, a UNEP Synthesis Report; United Nations Environment Programme (UNEP): Nairobi, Kenya, 2015.

43. Isenhour, C.; Feng, K. Decoupling and displaced emissions: On Swedish consumers, Chinese producers and policy to address the climate impact of consumption. J. Clean. Prod. 2016, 134, 320-329. [CrossRef] 
44. Swedish EPA. Consumption-Based Indicators in Swedish Environmental Policy; Swedish EPA: Stockholm, Sweden, 2012.

45. Swedish EPA. Konsumtionsbaserade Utsläpp av Växthusgaser i Sverige Och $i$ Andra Länder [Emissions from Swedish Consumption in Sweden and Abroad]; Swedish EPA: Stockholm, Sweden, 2012.

46. United Nations Department of Economic and Social Affairs (DESA). World Population Prospects: The 2015 Revision; United Nations Department of Economic and Social Affairs: New York, NY, USA, 2015.

47. Swedish Energy Agency Energy in Sweden Fact and Figures 2016. Available online: http://www. energimyndigheten.se/statistik/energilaget/ (accessed on 21 October 2016).

48. Turner, B.L.; Lambin, E.F.; Reenberg, A. The emergence of land change science for global environmental change and sustainability. Proc. Natl. Acad. Sci. USA 2007, 104, 20666-20671. [CrossRef] [PubMed]

49. Swedish Government Swedish Environmental Objectives. Etappmålen, Biologisk Mångfald [Milestone Target for Biodiversity and Ecosystem Services]; Swedish Government: Stockholm, Sweden, 2010.

50. Rees, W.; Wackernagel, M. Ecological Footprints and Appropriated Carrying Capacity: Measuring the Natural Capital Requirements of the Human Economy; Island Press: Washington, DC, USA, 1994.

51. Wilting, H.C.; Vringer, K. Carbon and land use accounting from a producer's and a consumer's perspective-An empirical examination covering the world. Econ. Syst. Res. 2009, 21, 291-310. [CrossRef]

52. Lenzen, M.; Murray, S.A. A modified ecological footprint method and its application to Australia. Ecol. Econ. 2001, 37, 229-255. [CrossRef]

53. Tukker, A.; Bulavskaya, T.; Giljum, S.; de Koning, A.; Lutter, S.; Simas, M.; Stadler, K.; Wood, R. The Global Resource Footprint of Nations: Carbon, Water, Land and Materials Embodied in Trade and Final Consumption. Available online: http://www.truthstudio.com/content/CREEA_Global_Resource_ Footprint_of_Nations.pdf (accessed on 21 October 2016).

54. Sandström, V.; Saikku, L.; Antikainen, R.; Sokka, L.; Kauppi, P. Changing impact of import and export on agricultural land use: The case of Finland 1961-2007. Agric. Ecosyst. Environ. 2014, 188, 163-168. [CrossRef]

55. Borucke, M.; Moore, D.; Cranston, G.; Gracey, K.; Iha, K.; Larson, J.; Lazarus, E.; Morales, J.C.; Wackernagel, M.; Galli, A. Accounting for demand and supply of the biosphere's regenerative capacity: The National Footprint Accounts' underlying methodology and framework. Ecol. Indic. 2013, 24, 518-533. [CrossRef]

56. Global Footprint Network. National Footprint Accounts, 2015 Editon; Global Footprint Network: Oakland, CA, USA, 2015.

57. Statistics Sweden Riksdagsval—Valda Efter Kön. Parliament Elections: Proportion of Elected Members by Gender. Available online: http://www.scb.se/sv_/Hitta-statistik/Statistik-efter-amne/Demokrati/ Allmanna-val/Allmanna-val-nominerade-och-valda/12352/12359/Riksdagsval/160728/ (accessed on 21 October 2016).

58. Statistics Sweden. På tal om Kvinnor och Män Lathund om Jämställdhet 2014 [Women and Men in Sweden 2014 Facts and Figures]; Statistics Sweden: Stockholm, Sweden, 2014.

59. The Power to Shape Society and Your Own Life: Towards New Gender Equality Policy Objectives. Available online: http:/ / eige.europa.eu/gender-mainstreaming/resources/sweden/govt-bill-2005-06155-makt-attforma-samhallet-och-sitt-eget-liv-nya-mal-i-jamstalldhetspolitiken (accessed on 21 October 2016).

60. Public Health Objectives. Swedish Government Government Bill 2002/03:35; The Government Offices: Stockholm, Sweden, 2002.

61. Public Health Agency of Sweden Ämnesområden: Delaktighet Och Inflytande i Samhället [Themes: Participation and Influence in Society]. Available online: https://www.folkhalsomyndigheten.se/ amnesomraden/livsvillkor-och-levnadsvanor/folkhalsans-utveckling-malomraden/delaktighet-ochinflytande-i-samhallet/ (accessed on 21 October 2016).

62. Nussbaum, M. Women's Capabilities and Social Justice. J. Hum. Dev. 2000, 1, 219-247. [CrossRef]

63. Statistics Sweden. Ojämn Fördelning av Makten [Unequal Distribution of Power]. Available online: http:// www.scb.se/statistik/_publikationer/LE0001_2012K01_TI_07_A05TI1201.pdf (accessed on 21 October 2016).

64. Statistics Sweden. Integration-En beskrivning av Läget i Sverige [Integration-A Description of the Situation in Sweden]; Statistics Sweden: Stockholm, Sweden, 2013.

65. Maxwell, S. The Meaning and Measurement of Poverty. ODI Poverty Brief. 1999, 3, 1-4.

66. Watkins, K. Human Development Report 2007/2008: Fighting Climate Change; United Nations Development Programme: New York, NY, USA, 2007. 
67. Swedish Government. Svensk Författningssamling, SFS nr: 1974:152. [The Swedish Instrument of Government]; The Government Offices: Stockholm, Sweden, 1974.

68. Gorz, A. Reclaiming Work: Beyond the Wage-Based Society; Polity: Cambridge, UK, 1999.

69. Paulsen, R. Arbetssamhället-Hur Arbetet Överlevde Teknologin. Available online: https://www.gleerups. se/40671370-product (accessed on 21 October 2016).

70. Public Health Agency of Sweden Ämnesområden: Ekonomiska och Sociala Förutsättningar. [Themes: Economic and Social Conditions]. Available online: https://www.folkhalsomyndigheten.se/ amnesomraden/livsvillkor-och-levnadsvanor/folkhalsans-utveckling-malomraden/ekonomiskaoch-sociala-forutsattningar/ (accessed on 21 October 2016).

71. Ringenson, K. The Foundation upon Which Society Is Built; KTH: Stockholm, Sweden, 2014.

72. Swedish National Board of Health and Welfare. Hemlöshetens Omfattning i Sverige [The Extent of Homelessness in Sweden]; Swedish National Board of Health and Welfare: Stockholm, Sweden, 2012; pp. 1-6.

73. Swedish Government. Swedish Education Act 2010:800; The Government Offices: Stockholm, Sweden, 2010.

74. Swedish National Agency for Education. Skolverkets Lägesbedömning 2013 [The Agency's Status Report on Education in English]; Swedish National Agency for Education: Stockholm, Sweden, 2013.

75. Burström, B.; Schultz, A.; Burström, K.; Fritzell, S.; Irestig, R.; Jensen, J.; Lynöe, N.; Marttila, A.; Sun, S. Hälsa Och Livsvillkor Bland Socialt Och Ekonomiskt Utsatta Grupper i Stockholms Län. Available online: https://kiedit.ki.se/sites/default/files/rapport_utsatta_grupper_070823.pdf (accessed on 21 October 2016).

76. Millennium Ecosystem Assessment. Ecosystems and Human Well-Being: Synthesis (Millennium Ecosystem Assessment); Island Press: Washington, DC, USA, 2005.

77. Harvey, D. Justice, Nature and the Geography of Difference; Blackwell: Oxford, UK, 1996; Volume 87.

78. Hull, K. Understanding the Relationship between Economic Growth, Employment and Poverty Reduction. In Promoting Pro-Poor Growth: Employment; OECD: Paris, France, 2009; pp. 69-94.

79. World Bank. World Development Report 2013: Jobs; The World Bank: Washington, DC, USA, 2012.

80. Okere ke, C. Equity Norms in Global Environmental Governance. Glob. Environ. Politics 2008, 8, 25-50. [CrossRef]

81. Räty, R.; Carlsson-kanyama, A. Comparing Energy Use by Gender, Age and Income in some European Countries; Swedish Defence Research Agency: Stockholm, Sweden, 2009.

82. Pachauri, S.; Spreng, D. Direct and indirect energy requirements of households in India. Energy Policy 2002, 30, 511-523. [CrossRef]

83. Reinders, A.H.M.E.; Vringer, K.; Blok, K. The direct and indirect energy requirement of households in the European Union. Energy Policy 2003, 31, 139-153. [CrossRef]

84. Dearing, J.A.; Wang, R.; Zhang, K.; Dyke, J.G.; Haberl, H.; Hossain, M.S.; Langdon, P.G.; Lenton, T.M.; Raworth, K.; Brown, S.; et al. Safe and just operating spaces for regional social-ecological systems. Glob. Environ. Chang. Policy Dimens. 2014, 28, 227-238. [CrossRef]

85. Baard, P.; Björnberg, K.E. Cautious utopias: Environmental Goal-setting with Long Time Frames. Ethics Policy Environ. 2015, 18, 187-201. [CrossRef]

(c) 2016 by the authors; licensee MDPI, Basel, Switzerland. This article is an open access article distributed under the terms and conditions of the Creative Commons Attribution (CC-BY) license (http://creativecommons.org/licenses/by/4.0/). 